\title{
A Low-Cost Method for Measuring Air Infiltration Rates in a Large Sample of Dwellings
}

Richard A. Grot

Building Thermal and Service Systems Division Center for Building Technology National Engineering Laboratory National Bureau of Standards Washington, D.C. 20234

April 1979

\section{Prepared for}

:ommunity Services Administration 200 19th Street, NW 



\section{A LOW-COST METHOD FOR \\ MEASURING AIR INFILTRATION RATES \\ IN A LARGE SAMPLE OF DWELLINGS}

Richard A. Grot

Building Thermal and Service Systems Division

Center for Building Technology

National Engineering Laboratory

National Bureau of Standards

Washington, D.C. 20234

April 1979

Prepared for

Community Services Administration

1200 19th Street, NW

Washington, D.C. 20036

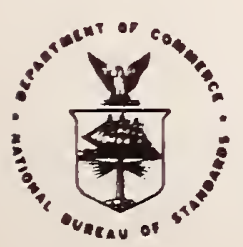

U.S. DEPARTMENT OF COMMERCE, Juanita M. Krops, Secretary

Dr. Sidney Harman. Under Secretany

Jordan J. Baruch, Assistant Secretary for Science and Technology

NATIONAL BUREAU OF STANDARDS, Ernest Ambler, Director 

A LOW-COST METHOD FOR MEASURING AIR INFILTRATION

RATES IN A LARGE SAMPLE OF DWELLINGS

\section{Richard A. Grot}

A method for collecting air infiltration data in a large sample of dwellings is presented. The method consists of a tracer-gas dilution technique employing air sample bags which are analyzed in a central laboratory. The method will be applied to a Community Services Administration optimal weatherization demonstration in approximately 300 dwellings on 16 sites throughout the United States. The method will yield air exchange rates under typical heating season condition for each dwelling in the demonstrations. Preliminary data on air infiltration rates in low-income housing in Portland, Maine are presented.

Key Words: Air infiltration; air sample bags; energy conservation; retrofit; sulfur hexafluoride; tracer gas; weatherization. 

The leakage of air into and out of the living space of a dwelling is one of the major components of heat loss of a home. Though recent advances in instrumentation have made it possible to automatically measure the air leakage rate of a building, the techniques to obtain actual air leakage rates are both expensive and difficult. In an attempt to measure the actual air infiltration rates in low-income housing and to determine the effectiveness of various weatherization measures on reducing the air leakage in a home, a measurement technique using a tracer gas and air sample bags has been developed. Preliminary data on air leakage rates from homes in Portland, Maine have been collected. These measurements are part of an evaluation of a weatherization project undertaken by the Community Services Administration.

The Community Services Administration (CSA), in order to assess how it might help poor people to cope with increasing energy costs, has undertaken a weatherization demonstration project whose major goal is to provide data for determining the optimal level of weatherization which should be applied to the residences occupied by the poor in various climatic zones in the continental United States. The Center for Building Technology of the National Bureau of Standards (NBS) has been given the role of providing technical assistance and support for this demonstration. This role involves selecting demonstration cities, selecting homes in each city, selecting weatherization options both for the building envelope and the buildings'mechanical system, supervising the collection of the data from the demonstration, developing test procedures for evaluating the effect of weatherization on the homes, and analyzing the results of the demonstration. The demonstration project is to be undertaken in 16 cities. These are graphically shown in Figure 1, along with the degree days for each location. At each site, approximately 20 to 30 homes will be weatherized.

The principal measure of the effectiveness of the weatherization of each dwelling will be the observed reduction in the utility bills of the dwelling. However, in order to assess in more detail the savings from each option and to explain anticipated variations in the amount of saving accrued among the homes, a series of tests for both the building envelope and the mechanical system has been developed. The building envelope tests currently being planned consist of: 1) a thermographic survey of the exterior of the dwellings, 2) air infiltration tests, 3) determination of the interior temperature stratification, and 4) the determination of the existence of heat by-pass mechanisms into attic and basement. The infiltration tests will consist of: 1) a test method for determining the actual air leakage rates in each dwelling, 2) a fan pressurization test, and 3) a test for locating the air leakage paths still existing in the dwelling after weatherization, employing fan depressurization and an infrared scanner. The topic of this paper is to describe the test method for determining the air leakage rate in each dwelling. 


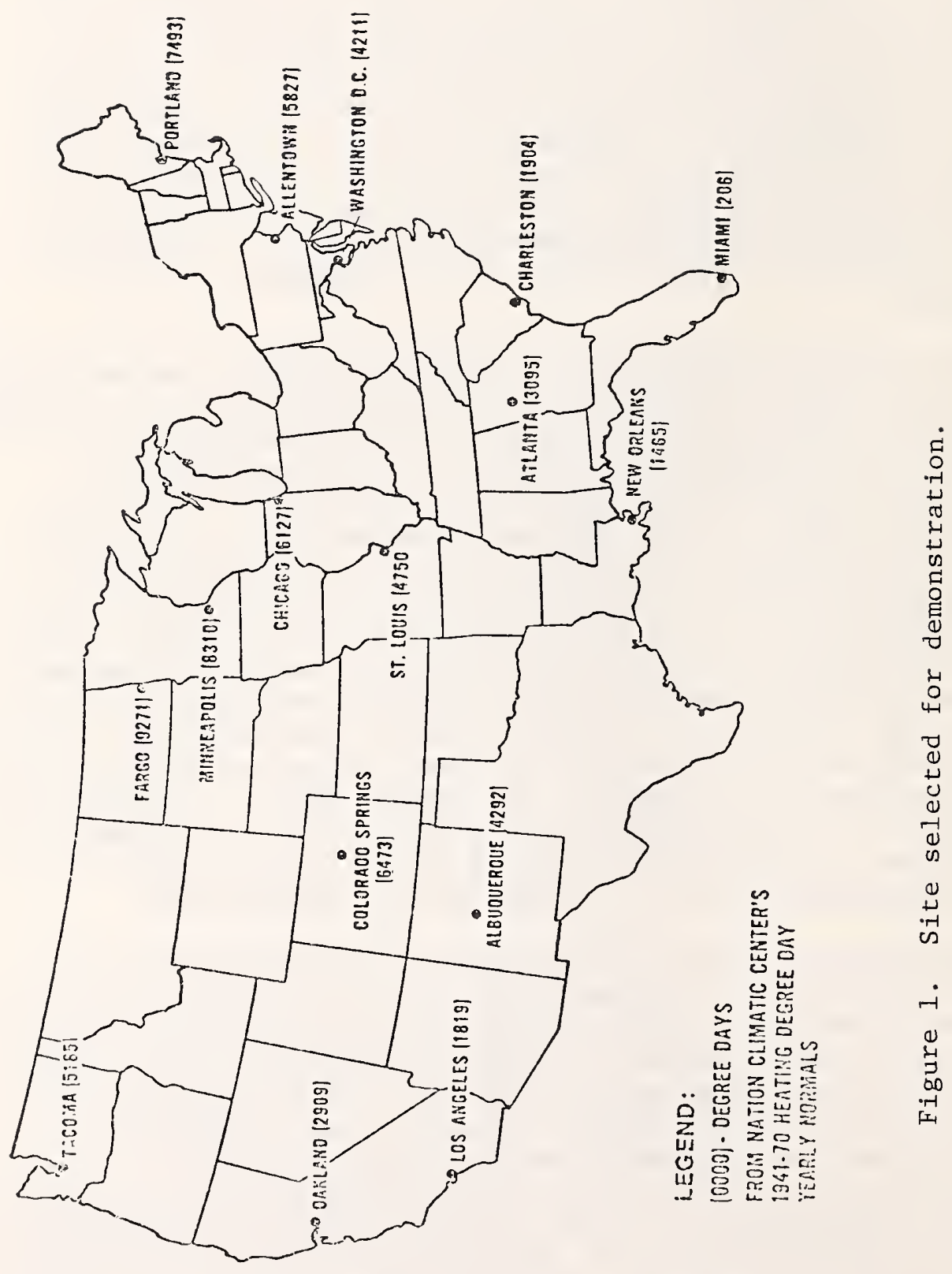


In attempting to assess the air leakage charcteristics of a dwelling, in the author's opinion, four classes of questions are usually asked: 1) what are the actual air leakage rates occurring in the structure under various climatic conditions and usage patterns; 2) how tight is the building compared with other buildings and with itself after certain measures are applied to the building; 3) where are the leakage paths in the structure; and 4) what is the severity of each air leakage path. The actual air infiltration rate of a building is usually determined by the tracer-gas dilution method [1,2]. The tightness of a building can be obtained by the tracer-gas method, but the fan pressurization method is easier to perform [3-5]. The location of air leakage paths can be observed using thermography, either under normal weather conditions [6] or in conjunction with pressurization of the building [5]. It is very difficult to determine the amount of air leakage attributable to each air leakage path. Attempts at this level of quantification usually consist of sealing the observed openings and using either the tracer-gas method or the pressurization method to determine the reduction in air leakage.

As mentioned above, the actual air infiltration rates in dwellings are usually determined by the tracer-gas technique. In the CSA weatherization demonstration, one would like to know the actual air leakage rates in each of the demonstration homes, at least after weatherization has been performed and preferably both before and after weatherization. Though the tracer-gas technique has the reputation of being difficult to perform and requires both highly trained personnel and expensive equipment, it is the author's opinion that this method can be modified through the use of air sample bags such that it can be applied to a large collection of dwellings by relatively inexperienced persons (possibly even the building occupant) in an inexpensive manner. The method will provide actual air exchange rates under various weather conditions which can be used to assess the typical air leakage performance of the building. The following sections will describe this method. 
The normal tracer-gas technique for measuring air infiltration consists of injecting a quantity of tracer gas into a building in such a manner that the tracer gas is well mixed and then to measure the rate of decay of this tracer gas using appropriate monitoring equipment. Sulfur hexafluoride $\left(\mathrm{SF}_{6}\right)$ is becoming extremely popular for this type of work and this paper will be restricted to that tracer gas. Normally after assuring that the initial quantity of tracergas is well mixed in the dwelling, concentration measurements are made at 5- to 15-minute intervals. The air exchange rate is determined by fitting the best exponential curve to the concentration decay data. The main reasons that this method is complicated and expensive are: 1) the concentration monitoring equipment is costly; 2) its use requires highly trained technicians; and 3) the duration of the test is usually 2 to 4 hours. In principle, the method leads to a detailed record of air exchange rates during the period of the test; however, an error analysis (see Hunt [1]) shows that for short time durations small errors in the determination of the concentration lead to significant errors in the determination of the air exchange rate. Also for the purpose of assessing the effect of air infiltration on the building heating load, the average air exchange rate over a period of one or two hours is of primary interest. For the CSA weatherization project, one would like to obtain for each weatherized dwelling this average air exchange rate under 5 to 10 different weather conditions which are more or less representative of the varying conditions experienced by the building during the heating season. It would require at least one trained technician and one $\mathrm{SF}_{6}$ concentration-monitoring apparatus per city to obtain this quantity of data. The resources for this, both monetary and personne1, are not available.

The proposed method for obtaining these data for the CSA weatherization demonstrations consists basically of replacing the determination of the decay rate of the tracer gas by concentration monitoring equipment deployed in the building with the analysis in the laboratory of air sample bags filled at intervals of one to two hours duration. The testing of the building would be undertaken in a process consisting of seven steps. The steps are graphically shown in Figure 2.

\section{Step 1: Injection of Tracer Gas $\left(\mathrm{SF}_{6}\right)$ into the Dwelling}

A predetermined quantity of the tracer gas $\mathrm{SF}_{6}$ is initially injected into the building such that the initial concentration of $\mathrm{SF}_{6}$ is 100 to $150_{3}$ parts per billion or approximately 10 to $15 \mathrm{ml}$ of $\mathrm{SF}_{6}$ per $1000 \mathrm{~m}^{3}$ of living space. The author has been using $30 \mathrm{~m} \ell$ graduated syringes for this injection. These can be prepared before the test or filled from a bottle of compressed $\mathrm{SF}_{6}$ at the site. The injection is accomplished by slowly walking along the dwelling injecting gas into each room in a quantity approximately portional to the volume of the room. The graduation on the syringe greatly aids in this process. 
STEP 1

INIECTION

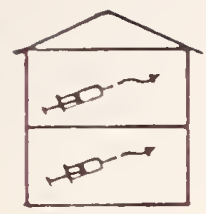

STEP 3

FILL SAMPLE

BAG

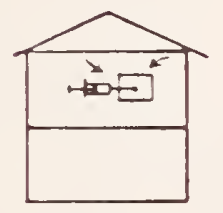

STEP 5

FILL 2nd

SEHPLE BAG

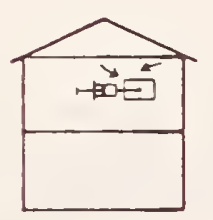

STEP 2

MIXING

$1 / 2-1$ hi
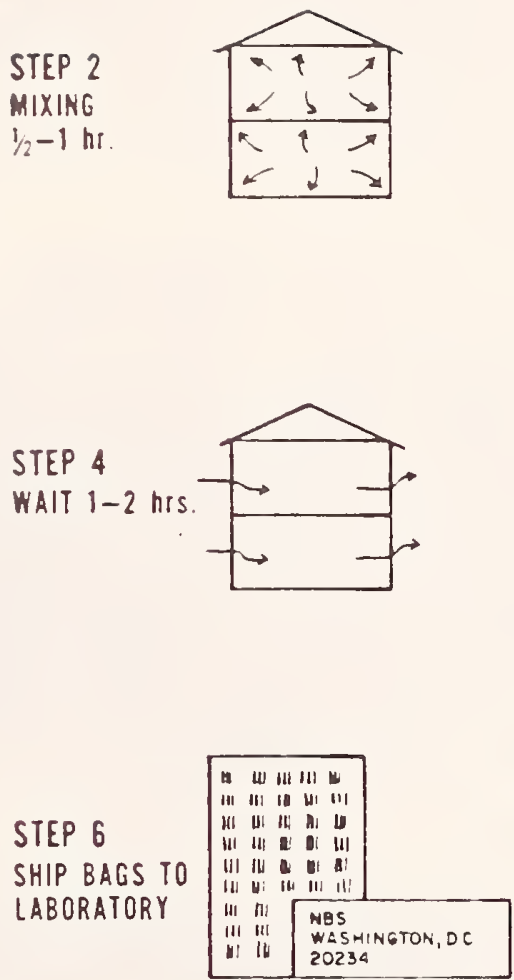

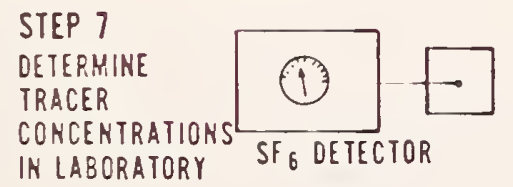

FIELD

EQUIPMENT
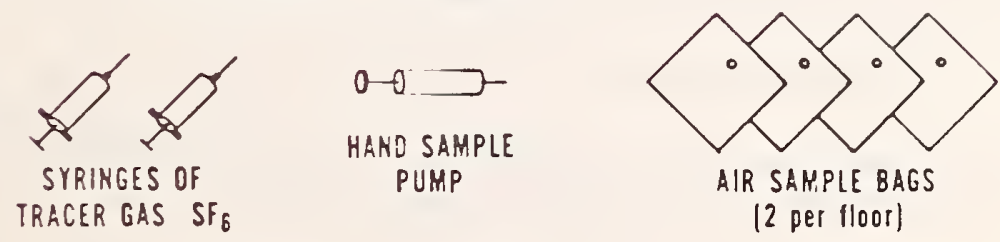

Figure 2. Outline of procedure. 
A waiting period of approximately $1 / 2$ hour to 1 hour should then be allowed for proper mixing of the tracer gas. For a building with a forced air heating system, the fan on the furnace can be turned on to assist in the mixing; however, the author's experience is that natural convection currents even in dwellings without an air handling system will well mix the tracer gas at least on each floor of the building (if the doors between rooms are open). There does seem to be a tendency for the concentration of the tracer gas to be higher on the upper floors, probably due to the natural convection currents caused by rising warm air.

\section{Step 3: Fill Initial Sample Bags}

After adequate mixing of the tracer gas an initial air sample bag is filled for each floor of living space. This is accomplished by walking around the floor filling the bag in the process with a small sample pump. This will provide an integrated sample. The author has been using a 10-1iter, five-layer air sample bag and either a hand pump (the type used to fill footballs and basketballs) or a small portable battery-powered pump. The important criterion is that the air sample bag must be filled slowly, thus ensuring that an integrated sample be obtained (the hand pump requires about fifty strokes to fill the bag, the battery pump approximately five minutes).

\section{Step 4: Decay of Tracer Gas}

One then waits one or two hours for the tracer gas to decay. During this period the occupants of the dwelling undergo their normal activities and the mechanical system is left in its normal operating mode.

\section{Step 5: Fill Final Sample Bags}

The procedure in step 3 is repeated obtaining a second sample bag of air for each floor of the building.

\section{Step 6: Ship Sample Bags to Laboratory}

The sample bags are then shipped to a center laboratory (in this case the National Bureau of Standards) for analysis.

\section{Step 7: Determination of Tracer Gas Concentration}

The tracer gas concentrations are determined in the central laboratory using an electron-capture gas chromatograph. The air infiltration rate $A I$ is then determined by the equation

$$
A I=\frac{1}{\Delta \tau} \ln \left(C_{1} / C_{2}\right)
$$


where $C_{1}$ and $C_{2}$ are the initial and final tracer gas concentrations respectively, and $\Delta \tau$ is the time interval in hours between filling of the sample bags. For periods of 1 to 2 hours, equation ( 1 ) is an accurate manner for determining the air exchange (see Ref. [1]). The above steps are graphically shown in Figure 2.

The above-described method is easy to perform and inexpensive, and if several homes are grouped together can be accomplished at the rate of about 1 house per hour.

\section{RESULTS OF PRELIMINARY TES'TING}

In order to assess the viability of the method for collecting air infiltration data, series of tests were run both in Portland, Maine in the dwellings that are being weatherized, and in a home in Maryland near the National Bureau of Standards. The first series of tests in Portland was done in order to obtain primary air exchange rates and in order to test the assumption of uniform mixing when the previously described injection procedure was applied. The concentration of $\mathrm{SF}_{6}$ was measured at several points on each floor of the tested building. Usually no variations in tracer concentration occurred which would lead to appreciable errors in the air exchange rate for the floor. As mentioned previously, there was a tendency for the concentration of the tracer gas to be higher on the upper floors than on the lower floors. This observation was the main reason for specifying in the test procedure that separate air sample bags be used for each floor of the building. A summary of the air exchange rates for this test is given in Table 1. The house numbers marked with an asterisk* are buildings which have already been weatherized. These data showed that these buildings were experiencing relatively high air exchange rates.

In order to test the feasibility of using air sample bags, tests were run in a home in Maryland. The sample bags were first analyzed the day immediately following the collection of the sample. An air infiltration rate of 0.34 air exchange per hour was found. After a period of three weeks the sample bags were reanalyzed and an air infiltration rate of 0.31 was obtained. Any change in concentration in the gas sample was within the errors of the experiment, since no care was taken to calibrate the instrument at these times.

\section{CONCLUSIONS}

The preliminary testing of this method has indicated that it is a feasible method for obtaining air infiltration data at a low cost and using inexperienced personnel. Although the method does not produce a detailed trace of air exchange rate over a period of one to two hours, it does give the total air leakage of that period, and this is usually of primary interest to energy conservation analysis. The technique also produces integrated air samples for each floor and therefore minimizes the effects of non-uniform mixing. 
TABLE 1

SUMMARY OF AIR INFILTRATION RATES - PORTLAND, ME.

Air Exchange Rate $\left(\mathrm{hr}^{-1}\right)$ Wind

\begin{tabular}{|c|c|c|c|c|c|c|c|c|}
\hline 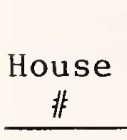 & $\begin{array}{l}\text { First } \\
\text { Floor }\end{array}$ & $\begin{array}{l}\text { Second } \\
\text { Floor }\end{array}$ & $\begin{array}{l}\text { Third } \\
\text { Floor } \\
\end{array}$ & $\begin{array}{c}\text { Duration } \\
\text { Test } \\
(\mathrm{hr}) \\
\end{array}$ & $\begin{array}{c}\text { Inside } \\
\text { Temp } \\
\left({ }^{\circ} \mathrm{C}\right) \\
\end{array}$ & $\begin{array}{c}\text { Outside } \\
\text { Temp } \\
\left({ }^{\circ} \mathrm{C}\right)\end{array}$ & $\begin{array}{c}\text { Direction } \\
\& \text { Speed } \\
\mathrm{km} / \mathrm{hr}\end{array}$ & $\begin{array}{l}\text { House } \\
\text { Volyme } \\
\left(\mathrm{m}^{3}\right) \\
\end{array}$ \\
\hline 7 & 0.78 & 0.98 & - & 1.4 & 21.1 & -7.8 & $\begin{array}{l}N-N W \\
0-16 \\
\end{array}$ & 311 \\
\hline $10 *$ & 0.93 & - & - & 2.0 & 24.4 & 2.8 & $\begin{array}{l}N-N W \\
0-16 \\
\end{array}$ & 224 \\
\hline 11 & 0.95 & 0.93 & - & 2.4 & 21.6 & 0.0 & $\begin{array}{l}N-N W \\
0-16 \\
\end{array}$ & 161 \\
\hline $12 *$ & 1.52 & 1.57 & - & 1.6 & 20.5 & -5.6 & $\begin{array}{l}\mathrm{N}-\mathrm{NW} \\
0-16 \\
\end{array}$ & 274 \\
\hline 15 & 1.96 & 1.99 & 1.67 & 1.4 & 20.0 & -0.6 & $\begin{array}{l}N-N W \\
0-16 \\
\end{array}$ & 747 \\
\hline 18 & 1.10 & 1.17 & - & 2.5 & 21.6 & 0.0 & $\begin{array}{l}\mathrm{N}-\mathrm{NW} \\
0-16 \\
\end{array}$ & 490 \\
\hline 19 & 1.83 & 1.68 & 1.97 & 1.4 & 21.1 & 2.8 & $\begin{array}{l}N-N W \\
0-16 \\
\end{array}$ & 441 \\
\hline $23 *$ & 0.99 & 1.19 & - & 2.0 & 22.2 & 0.0 & $\begin{array}{l}N-N W \\
24-48\end{array}$ & 498 \\
\hline $25^{*}$ & 0.80 & 0.87 & - & 2.5 & 18.9 & 0.6 & $\begin{array}{l}\mathrm{N}-\mathrm{NW} \\
0-16 \\
\end{array}$ & 501 \\
\hline $26 *$ & 1.21 & 1.578 & - & 0.8 & 20.0 & 0.0 & $\begin{array}{l}N-N W \\
24-46 \\
\end{array}$ & 453 \\
\hline
\end{tabular}

* These homes have been weatherized. 
The analysis of the air sample bags in the laboratory permits the use of standard laboratory techniques, such as dilution of the sample if the concentration of gas is above the saturation concentration of the detector, and the use of reference concentrations for each range of sensitivity of the detector--techniques which are difficult to apply in the field. The major disadvantage of this method is that it is a blind test and there are no checks in the field which can assure the accuracy to which the instructions are followed. It is planned to modify the automatic air infiltration equipment described in Reference [7] such that it can automatically handle 40 bags at a time. The possibility of automatically processing the air sample bags is the reason that air sample bags as large as 10 liters were chosen. The technique will be applied during the 1978-1979 heating seasons to the CSA weatherization demonstrations and further verification of its accuracy and reliability will be undertaken. 


\section{REFERENCES}

1. C. M. Hunt, "Air Infiltration: A Review of Some Existing Measurement Techniques and Data," Proceedings of ASTM Symposium on Air Infiltration and Air Change Rate Measurement, March 1978.

2. P. L. Lagus, "Air Infiltration Measurement by the Tracer Dilution Method," Proceedings of ASTM Symposium on Air Infiltration and Air Change Rate Measurement, March 1978.

3. G. T. Tamara, "Measurement of Air Leakage Characteristics of House Enclosures," ASHRAE Transactions, Vol. 81, Part 1, p. 202-211, 1975.

4. S. Stricker, "Measurements of Air-Tightness of Houses," ASHRAE Transactions, Vol. 81, Part 1, p. 148-167, 1975.

5. J. Kronva11, "Testing of Houses for Air Leakage Using a Pressure Method," ASHRAE Transactions, Vol. 84, Part 1, p. 72-79, 1978.

6. R. A. Grot, D. T. Harrje, L. C. Johnston, "Application of Thermography for Evaluating Effectiveness of Retrofit Measures," Proceedings of Third Biennial Infrared Information Exchange, AGA Corporation, Secaucus, N.J., p. 103-117, 1977.

7. D. T. Harrje and R. A. Grot, "Automated Air Infiltrations Measurements and Implications for Energy Conservation," Proceedings of International Conference Energy Use Management, Vol. 1, p. 457-464, Pergamon Press, N.Y., 1977.

\section{ACKNOWLEDGEMENTS}

The author wishes to acknowledge the many fruitful conversations he has had with David T. Harrje of Princeton University on this topic. 
NBS.114A IREV. 0.78)

\begin{tabular}{|c|c|c|c|}
\hline $\begin{array}{l}\text { U.S. DEPT. OF COMM. } \\
\text { BIBLIOGRAPHIC DATA } \\
\text { SHEET }\end{array}$ & $\begin{array}{l}\text { 1. PUBLICATION OR REPORT NO. } \\
\text { NBSIR } 79-1728\end{array}$ & 2.Gov't. Accession No & 3. Recipient's Accession No. \\
\hline \multirow{2}{*}{\multicolumn{3}{|c|}{$\begin{array}{l}\text { 4. TITLE AND SUBTITLE } \\
\text { A LOW-COST METHOD FOR MEASURING AIR INFILTRATION RATES } \\
\text { IN A LARGE SAMPLE OF DWELLINGS }\end{array}$}} & $\begin{array}{l}\text { 5. Publication Date } \\
\text { Apri1 } 1979 \\
\end{array}$ \\
\hline & & & 6. Performing Organization Code \\
\hline \multicolumn{3}{|l|}{$\begin{array}{l}\text { 7. AUTHOR(S) } \\
\text { Richard A. Grot }\end{array}$} & $\begin{array}{l}\text { 8. Performing Organ. Report No. } \\
7422500\end{array}$ \\
\hline \multicolumn{3}{|c|}{$\begin{array}{l}\text { 9. PERFORMING ORGANIZATION NAME AND ADDRESS } \\
\text { NATIONAL BUREAU OF STANDARDS } \\
\text { DEPARTMENT OF COMMERCE } \\
\text { WASHINGTON, DC } 20234\end{array}$} & \begin{tabular}{|l|} 
10. Project/Task/Work Unit No. \\
11. Contract/Grant No.
\end{tabular} \\
\hline \multicolumn{3}{|c|}{$\begin{array}{l}\text { 12. SPONSORING ORGANIZATION NAME AND COMPLETE ADDRESS (street, City, State, ZIP) } \\
\text { Community Services Administration } \\
120019 \text { th Street, NW } \\
\text { Washington, D.C. } 20036\end{array}$} & 13. Type of Report \& Period Covered \\
\hline
\end{tabular}

15. SUPPLEMENTARY NOTES

Document describes a computer program; SF-185, FIPS Software Summary, is attached.

16. ABSTRACT (A 200-word or less factual summary of most significant information. If document includes a significant bibliography or literature survey, mention it here.)

A method for collecting air infiltration data in a large sample of dwellings is presented. The method consists of a tracer gas dilution technique employing air sample bags which are analyzed in a central laboratory. The method will be applied to a Community Services Administration optimal weatherization demonstration in approximately 300 dwellings on 16 sites throughout the United States. The method will yield air exchange rates under typical heating season condition for each dwelling in the demonstrations. Preliminary data on air infiltration rates in low-income housing in Portland, Maine are presented.

17. KEY WORDS (six to twelve entries; alphabetical order; capitalize only the first letter of the first key word unless a proper name; separated by semicolons)

Air infiltration; air sample bags; energy conservation; retrofit; sulfur hexafluoride; tracer gas; weatherization.

18. AVAILABILITY

For Official Distribution. Do Not Release to NTIS

Order From Sup. of Doc., U.S. Government Printing Office, Washington, DC 20402, SD Stock No. SNÓ03-003-

X Order From National Technical Information Service (NTIS), Springfield, VA. 22161

\section{[x] Unlimited}

\begin{tabular}{|l|c|}
\hline $\begin{array}{l}\text { 19. SECURITY CLASS } \\
\text { (THIS REPORT) } \\
\text { UNCLASSIFIED }\end{array}$ & $\begin{array}{c}\text { 21. NO. OF } \\
\text { PRINTED PAGES }\end{array}$ \\
\hline $\begin{array}{l}\text { 20. SECURITY CLASS } \\
\text { (THIS PAGE) }\end{array}$ & 22 Price \\
UNCLASSIFIED & $\$ 4.00$ \\
\hline
\end{tabular}




